\title{
New taxonomical arrangement of the traditionally conceived genera Orthotrichum and Ulota (Orthotrichaceae, Bryophyta)
}

\author{
Vítězslav Plášek, Jakub Sawicki, Ryszard Ochyra, \\ Monika Szczecińska \& Tomasz Kulik
}

\begin{abstract}
New taxonomical arrangement of the traditionally conceived genera Orthotrichum and Ulota (Orthotrichaceae, Bryophyta). - Acta Mus. Siles. Sci. Natur., 64: 169-174, 2015.

Abstract: The traditionally conceived genera Orthotrichum Hedw. and Ulota F.Weber are here reclassified into six genera, Orthotrichum, Dorcadion Lindb., Nyholmiella Holmen \& E.Warncke, Pulvigera Plášek, Sawicki \& Ochyra, Plenogemma Plášek, Sawicki \& Ochyra, and Ulota, based on morphological differences and partially on molecular evidence. The genus Pulvigera includes P. lyellii (Hook. \& Taylor) Plášek, Sawicki \& Ochyra (Orthotrichum lyellii Hook. \& Taylor) which was selected as its generitype. The genus Plenogemma includes $P$. phyllantha (Brid.) Plášek, Sawicki \& Ochyra (Ulota phyllantha Brid.) which was selected as its generitype.
\end{abstract}

Key words: Orthotrichum; Dorcadion; Nyholmiella; Plenogemma gen. nov.; Pulvigera gen. nov.; Ulota; moss taxonomy

\section{Introduction}

Orthotrichum Hedw. is a cosmopolitan moss genus consisting of 159 species (Sawicki, Plášek \& Szczecińska 2012) and it is the second largest genus in the family Orthotrichaceae. Taxonomic subdivision within this genus has been the subject of continued debate since the late $19^{\text {th }}$ century. Certain taxa were repeatedly included in or removed from the genus Orthotrichum in an attempt to better clarify infrageneric taxa, including subgenera and sections. The history of taxonomic classification of the genus Orthotrichum has been described in detail by Lewinsky (1993) and Lewinsky-Haapasaari and Hedenäs (1998). A phylogenetic analysis revealed the polyphyletic nature of the genus (Goffinet, Bayer \& Vitt 1998; Goffinet et al. 2004; Sawicki, Plášek \& Szczecińska 2009, 2010).

Previous research has demonstrated that the debate on the evolution and taxonomy of the genus Orthotrichum would not be complete without including those species of the genus Ulota whose close links to Orthotrichum subgenus Gymnoporus (Braithw.) Limpr. have been proven by numerous studies (Goffinet, Bayer \& Vitt 1998; Goffinet et al. 2004; Sawicki, Plášek \& Szczecińska 2010).

The genus Ulota consists of around 60 species (Ramsay 2012), of which more than half are found only in the Southern Hemisphere.

Currently published phylogenetic studies (Goffinet et al. 2004; Sawicki, Plášek \& Szczecińska 2009, 2010) as well as ongoing phylogenetic studies based on complete organellar genomes fully support the taxonomic concept presented in this work.

\section{A re-circumscription of the genera Orthotrichum and Ulota}

The crucial feature for the reclassification of this group of taxa is the type and position of stomata. The only genus which has cryptoporous stomata is Orthotrichum s. str. Among the genera with phaneroporous stomata, an important character in the classification of taxa is the level of ploidy. Monoicous taxa include the genera Ulota and Dorcadion. Although they share superficial stomata and recurved leaf margins, species of Ulota can be easily distinguished from latter mainly by the presence of quadrate to rectangular hyaline cells forming a marginal border at leaf base. Moreover, in Ulota species brood bodies are never 
produced and asexual reproduction by propagules within species of Dorcadion is extremely rare. The group of dioicous genera can be characterized mainly by production of gemmae in great profusion and this apparently compensates for the apparently very rare incidence of sexual reproduction. The group consists of Nyholmiella, Pulvigera and Plenogemma, the last two taxa being recognized here as new genera. Nyholmiella differs from Pulvigera and Plenogemma primarily by having an ovate leaf with an obtuse apex. The latter two genera have leaves that are linear-lanceolate or lanceolate with an acute to acuminate apex. While the gemmae in Pulvigera are scattered more or less equally on the adaxial leaf surface, in Plenogemma the conspicuous clusters of fusiform brownish gemmae are situated on the protruding costa of the upper leaves.

\section{All six genera can be distinguished in the following key.}

1a. Stomata cryptoporous

1b. Stomata phaneroporous

2a. Monoicous; gemmae mostly absent

2b. Dioicous; gemmae always present

\section{Orthotrichum}

2

3

4

3a. Basal marginal cells of leaves shorter and pale with thickened cross-walls, forming a border sharply differentiated from inner cells

3b. Basal marginal cells of leaves not particularly differentiated

Ulota

Dorcadion

4a. Leaf margins erect, incurved or involute throughout; leaves ovate, concave, broadly obtuse or rounded at the apex

Nyholmiella

4b. Leaf margins plane above, partly recurved below; leaves lanceolate, narrower at the apex, acute or acuminate

5a. Gemmae forming conspicuous clusters on excurrent part of costa of uppermost leaves

5b. Gemmae scattered more or less equally on adaxial leaf surface

Plenogemma

Pulvigera

\section{Principal morphologic features of the genera}

The following characters are not an exhaustive list of the distinguishing features, but represent a selection of those that are of fundamental importance for taxonomic delimitation of individual genera.

\section{Orthotrichum Hedw.}

Spec. Musc.: 162. 1801. Lectotype: Orthotrichum anomalum Hedw. (fide Grout 1935: 106).

Species of Orthotrichum s. str. are characterized by having appressed to erect leaves, which are only occasionally flexuose when dry (e.g. O. pulchellum). They are narrowly lanceolate to oblong- or ovate-lanceolate, keeled, acuminate to acute or rounded with the margins mostly recurved. The costa is single, usually vanishing below the apex, rarely excurrent. Short cylindrical, unbranched gemmae are occasionally present on the leaves. Species of the genus are monoicous. The capsules are immersed to somewhat long exserted and mostly ribbed. The stomata are immersed. The vaginula is naked or hairy. The peristome is double or, rarely, reduced and single, with the teeth erect or reflexed on drying. The exostome consists of 16 teeth which are typically arranged in 8 pairs. The endostome contains 8 or 16 segments. The calyptra is naked or sparsely to densely hairy. 
Dorcadion Lindb.

Utkast Eur. Bladmoss.: 7. 1878. Lectotype (selected here): Dorcadion affine (Brid.) Lindb. (Orthotrichum affine Brid.)

Species of Dorcadion are characterized by having appressed to erect leaves that are narrowly lanceolate to oblong- or ovate-lanceolate, keeled, acuminate to acute or rounded with the margins mostly recurved. The costa is single, usually subpercurrent. Short cylindrical und unbranched gemmae are occasionally present on the leaves. Sexual condition is always monoicous. The capsules are immersed to somewhat long exserted, smooth or less often furrowed when dry. The stomata are superficial. The vaginula is naked or hairy. The peristome is double (rarely reduced or single), erect or reflexed when dry. It consists of 16 exostome teeth that are usually arranged in 8 pairs and an endostome of 8 or 16 segments. The calyptra is naked or sparsely to densely hairy.

The name Dorcadion was introduced by Adanson (1763) and as a pre-Hedwigian name it was subsequently validated by Lindberg (1878). These two authors placed in this genus three species which Dillenius (1741) placed in his genus Polytrichon for which he had used phrase names and presented on plate 55 in figures 8-10. In current taxonomic usage these are Dorcadion affine, D. stramineum (Hornsch.) Lindb. and D. rupestre (Schwägr.) Lindb. The first of these is here selected as a lectotype of this generic name.

\section{Nyholmiella Holmen \& E.Warncke}

Bot. Tidsskr. 65: 179. 1969. Lectotype: Nyholmiella obtusifolia (Brid.) Holmen \& E.Warncke (Orthotrichum obtusifolium Brid.) (fide Vitt 1971: 704).

Species of Nyholmiella have leaves erect-spreading when moist but loosely appressed when dry. They are ovate with bluntly rounded apices, erect, incurved or involute margins and a single costa that is obscure distally and ceases far below the apex. The gemmae are usually abundantly produced, primarily on the adaxial surface of the leaf lamina. They are uniseriate or with a few biseriate areas, branched (in N. gymnostoma (Brid.) Holmen \& Warncke) or unbranched (in $N$. obtusifolia). The plants are always dioicous. The capsules are immersed to somewhat emergent. The stomata are superficial and the vaginula is naked. The peristome is present only in $N$. obtusifolia and consists of 8 exostome teeth, which are reflexed on drying, and 8 endostome segments, whereas $N$. gymnostoma has gymnostomous capsules. The ca-lyptra is essentially glabrous.

The distinctness from other taxa of the genus Orthotrichum of the species now placed in the genus Nyholmiella has been already noted by Delogne (1885) and these differences were effected by Hagen (1908) who established the separate genus Stroemia I.Hagen to accommodate Orthotrichum gymnostomum and O. obtusifolium. Since Stroemia was an illegitimate name, it was replaced by Nyholmiella by Damsholt, Holmen \& Warncke (1969). This genus has not been universally accepted by bryologists (Vitt 1973; Goffinet et al. 2004; Sawicki, Plášek \& Szczecińska 2010) provided convincing molecular evidence to support of the generic distinctness of Nyholmiella.

Pulvigera Plášek, Sawicki \& Ochyra, gen. nov.

Orthotrichum Hedw. sect. Lyelliana Schimp., Syn. Musc. Eur. (ed. 2) 2: 336.1876 ['Orthotricha Lyelliana’]. Type: Orthotrichum lyellii Hook. \& Taylor, Musc. Brit.: 76, pl. 22. $1818 \equiv$ Pulvigera lyellii (Hook. \& Taylor) Plášek, Sawicki \& Ochyra, comb. nov.

Etymology: The generic name refers to the leaves that are covered with numerous brown gemmae giving them a dusty appearance.

Pulvigera is a monotypic genus comprising only $P$. lyellii which is its generitype. Although formerly placed in genus Orthotrichum, its position there is no longer sustainable 
with respect to its dioicous sexuality and the production of gemmae in great profusion. Moreover, the species has plane leaf margins.

The leaves are erect-spreading to loosely-erect when moist, but slightly contorted when dry, lanceolate to linear-lanceolate, narrowly acute to acuminate. The leaf margin is plane above but sometimes lightly recurved near the base. The costa is strong, ending near the apex.

Fertile plants with mature capsules have been recorded several times for Pulvigera lyellii but they are always considered to be very rare (Smith 2004). The stomata are superficial. Detailed description of the double peristome (16 exostome teeth +16 endostome segments) in this species was published by Lewinsky (1989) and Lewinsky-Haapasaari (1994).

Pulvigera lyellii are easily recognized mainly by the gemmae and sharply tipped leaves. Quantity of brownish gemmae situated over the leaf surfaces gives the impression that the leaves are dusty by them. Plenogemma phyllantha also has gemmae, but its leaves are strongly crisped when dry, and the gemmae cluster are situated rather on the leaf apices.

Plenogemma Plášek, Sawicki \& Ochyra, gen. nov.

Dense pulvinata, foliis longis, valde tortilis, lanceolatis longe acuminatisque, marginibus integris, planis in parte superiori, inferne recurvis, costis fuscis, longe styloso-excurrentibus, in parte stylosa foliorum supremorum densissime propagulis cylindraceis articulatis fuscis obtectis, cellulis superioribus ellipticis vel rotundatis cum (1-)2 papillis humilibus praeditis. Dioica. Capsulae perrarae, stomata phaneropora, peristomium duplex. Gemmae semper effecta. Type: Plenogemma phyllantha (Brid.) Sawicki, Plášek \& Ochyra, comb. nov. BASIONYM: Ulota phyllantha Brid., Mant. Musc.: 113. 1819.

Etymology: The generic name alludes to gemmae that are produced in great profusion on the excurrent part of the costa at the leaf apex.

Plenogemma is a monotypic genus comprising a single species, $P$. phyllantha, which serves as its generitype. Although formerly placed in Ulota, there are at least two undisputed features for its exclusion, namely the dioicous sexuality (and accordingly extremely rare production of sporophytes), and production of gemmae in great profusion on the excurrent costa. Moreover, the species has narrowly elongate basal laminal cells with nodose and incrassate lateral walls, not quadrate to rectangular hyaline cells as in Ulota s. str. species.

The leaves, on drying, are contorted to strongly crisped and erect-spreading when moist. They are ovate to narrowly lanceolate with acute apices. The leaf margin is plane or recurved below. The costa is brownish and protrudes from the tip, where a conspicuous cluster of brown gemmae is formed.

The sexual condition is dioicous and sporophytes are produced exceedingly rarely. The stomata are superficial but detail description of the sporophyte characters of $P$. phyllantha is usually absent in the literature.

Plenogemma phyllantha is easily recognized due to the mass-production of brownish to dark brown cylindrical and multi-septate gemmae formimg clusters on the excurrent part of the costa of the uppermost leaves. Some species of Orthotrichum and the two known species of Nyholmiella also produce gemmae on the leaves, but they are pale green, not brown. In Pulvigera lyellii gemmae are brown colored but they are scattered more or less equally on the leaf surface or very occasionally arise from the ends of rhizoids and protonema (Correns 1899; Piccioli 1932; Duckett \& Ligrone 1992; Lewinsky 1993).

SEM micrographs of the peristome in this species were published by Shaw (1986) who suggested that its peristome structure agrees well with that observed in species of the broadly conceived genus Orthotrichum. This argument may also support the transfer of the species from the genus Ulota to Plenogemma. 


\section{Ulota D.Mohr}

Ann. Bot. (König \& Sims) 2(3): 540. 1806. Type: Ulota crispa (Hedw.) Brid. (Orthotrichum crispum Hedw.).

Species of Ulota are characterized by having contorted-crisped to slightly twisted leaves that are erect-curved when dry. They are oblong- to linear-lanceolate, usually from an ovate base, acuminate, acute with the margins mostly recurved. The costa is percurrent. The inner basal laminar cells radiate from the insertion and are elongate-rectangular to elliptic, often with nodose and very incrassate walls. The leaf base also has a well differentiated border of one or few rows of quadrate to rectangular hyaline cells. Brood bodies are always absent. The plants are monoicous. The capsules are fully exserted and the stomata are superficial. The vaginula is naked or hairy. The peristome is double or single (if the endostome is lacking). The exostome consists of 8 or sometimes 16 reflexed or erect teeth. The endostome comprises 8 segments which may be lacking. The calyptra is conic, hairy and usually deeply split for several lobes at base.

All species of Ulota are monoicous and often produce sporophytes but never propagate vegetatively by gemmae. Ulota phyllantha has had always been a discordant element within the genus. It was the only dioicous species which produced sporophytes exceedingly rarely, but it reproduced very successfully by gemmae. The shape of the leaves in U. phyllantha differs from that of other congeners in the lack of an ovate base and by having an excurrent costa. These morphological differences are strongly supported by molecular data and accordingly $U$. phyllantha is transferred to the separate genus Plenogemma.

Acknowledgements: We are very grateful to Dr. Rod Seppelt (Tasmania) for linguistic corrections of the manuscript. The contribution by V. Plášek is part of a research project of the Institute of Environmental Technologies, reg. no. CZ.1.05/2.1.00/03.0100; Project LO1208 of the National Feasibility Programme I of the Czech Republic; Project No. 00955/2015/RRC „Podpora bilaterální spolupráce v oblasti VŠ vzdělávání, vědy a výzkumu mezi univerzitami z Moravskoslezského kraje a čínskými univerzitami a výzkumnými organizacemi“. This study was possible also through financial support from the Polish Ministry of Science and Higher Education (Grant Iuventus Plus IP2010-037070) for J. Sawicki. The contribution of R. Ochyra gained financial support from the Polish National Centre of Sciences through grant No. N N 303469338 and, in part, through the statutory fund of the Institute of Botany of the Polish Academy of Sciences.

\section{References}

Adanson M. (1763): Familles des plantes. Vol. 2. Vincent, Paris. 640 pp.

Correns C. (1899): Untersuchungen über die Vermehrung der Laubmoose durch Brutorgane und Stecklinge, Jena. $472 \mathrm{pp}$.

Damsholt K., Holmen K. \& Warncke E. (1969): A list of the bryophytes of Denmark. - Botanisk Tidsskrift 65: 163-183.

Delogne Ch. (1885): Flore cryptogamique de Belgique. - Annales de la Société Belge de Microscopie 9: 7 220.

Dillenius J.J. (1741): Historia muscorum. Oxonii (Oxford).

Duckett J.G. \& Ligrone R. (1992): A survey of diaspore liberation mechanisms and germination patterns in mosses. - Journal of Bryology 7: 335-354.

Goffinet B., Bayer R.J. \& Vitt D.H. (1998): Circumscription and phylogeny of the Orthotrichales (Bryopsida) inferred from $r b c L$ sequence analyses. - American Journal of Botany 85: 1324-1337.

Goffinet B., Shaw A.J., Cox C.J., Wickett N.J. \& Boles S. (2004): Phylogenetic inferences in the Orthotrichoideae (Orthotrichaceae: Bryophyta) based on variation in four loci from all genomes. -Monographs in Systematic Botany from the Missouri Botanical Garden 98: 270-289.

Grout A.J. (1935): Moss flora of North America, north of Mexico. Vol. 2. Newfane, Vermont.

Hagen I. (1908): Forarbejder til en norsk lovmosflora. I. Orthotrichaceae. Det Kongelige Norske Videnskabers Selskabs Skrifter 1907, 13: 1-100.

Lewinsky J. (1989): Does the orthotrichaceous type of peristome exist? A study of peristome evolution in the genus Orthotrichum Hedw. with possible derivation of the haplolepideous peristome. - Journal of the Hattori Botanical Laboratory 67: 335-363. 
- (1993): A synopsis of the genus Orthotrichum Hedw. (Musci, Orthotrichaceae). - Bryobrothera 2: 1-59.

Lewinsky-Haapasaari J. (1994): The genus Pleurorthotrichum Broth. - Lindbergia 19: 11-24.

Lewinsky-Haapasaari J. \& Hedenäs L. (1998): A cladistic analysis of the moss genus Orthotrichum. Bryologist 101: 519-555.

Lindberg S.O. (1878): Utkast till en naturlig gruppering af Europas bladmossor med toppsittande frukt (Bryinae acrocarpae). J. C. Frenckell \& Sons tryckeri, Helsingfors. 39 pp.

Piccioli E. (1932): Les espèces européennes du genre Orthotrichum. - Travaux de l'Institut de Botanique de l'Université de Neuchâtel 1: 1-128.

Ramsay H.P. (2012): Australian Mosses Online. 47. Orthotrichaceae: Ulota. Available: http://www.anbg.gov. au /abrs/Mosses_online/Orthotrichaceae_Ulota.pdf (2012). Accessed 1 October 2014.

Sawicki J., Plášek V. \& Szczecińska M. (2009): Preliminary studies on the phylogeny of the genus Orthotrichum inferred from nuclear ITS sequences. - Annales Botanici Fennici 46: 507-515.

- (2010): Molecular studies resolve Nyholmiella (Orthotrichaceae) as a separate genus. - Journal of Systematics and Evolution 48: 183-194.

- (2012): Molecular data do not support the current division of Orthotrichum (Bryophyta) species with immersed stomata. - Journal of Systematics and Evolution 50: 12-24.

Shaw J. (1986): Peristome structure in the Orthotrichaceae. - Journal of the Hattori Botanical Laboratory 60: 119-136.

Smith A.J.E. (2004): The Moss Flora of Britain and Ireland. Cambridge University Press, Cambridge, 1012 pp.

Vitt D.H. (1971): The infrageneric evolution, phylogeny, and taxonomy of the genus Orthotrichum (Musci) in North America. - Nova Hedwigia 21: 683-711.

- (1973) A revision of genus Orthotrichum in North America, north of Mexico. - Bryophytorum Bibliotheca 1: $1-208$.

Authors' addresses: Vítězslav Plášek, Dept. of Biology and Ecology, University of Ostrava, Chittussiho 10, CZ-710 00 Ostrava, Czech Republic.

E-mail: vitezslav.plasek@osu.cz

Jakub Sawicki, Department of Botany and Nature Protection, University Warmia and Mazury, Plac Łódzki 1, 10-728 Olsztyn, Poland and Dept. of Biology and Ecology, University of Ostrava, Chittussiho 10, CZ-710 00 Ostrava, Czech Republic.

E-mails: jakub.sawicki@uwm.edu.pl

Ryszard Ochyra, Laboratory of Bryology, Institute of Botany, Polish Academy of Sciences, Lubicz 46, 31-512 Kraków, Poland.

E-mails: r.ochyra@botany.pl

Monika Szczecińska \& Tomasz Kulik, Department of Botany and Nature Protection, University Warmia and Mazury, Plac Łódzki 1, 10-728 Olsztyn, Poland.

monika.szczecinska@uwm.edu.pl; tomasz.kulik@uwm.edu.pl 